УДК 621.314

НЕРУБАЦЬКИЙ В. П., к.т.н., доцент;

ПЛАХТІЙ О. А., к.Т.Н., доцент;

КАРПЕНКО Н. П., к.Т.Н., доцент;

ГОРДІЄНКО Д. А., аспірант;

ЦИБУЛЬНИК В. Р., магістрант

(Український державний університет залізничного транспорту)

\title{
Аналіз енергетичних процесів у семирівневому автономному інверторі напруги при різних алгоритмах модуляції
}

У статті досліджено реалізовані параметри якості вихідної напруги та вихідного струму в семирівневому автономному інверторі напруги з фіксованими діодами при реалізації різних алгоритмів модуляції. Розглянуто методи реалізації широтно-імпульсної модулящії. У середовищі Matlab / Simulink / SymPowerSystems розроблено модель семирівневого автономного інвертора напруги з розглянутими системами керування. Отримано результати імітаційного моделювання у вигляді енергетичних показників. Встановлено значення вихідної потужності, загальні коефічієнти гармонічних спотворень вихідної напруги та вихідного струму, а також значення втрат потужності в силових перемикачах. Наведено порівняльну таблицю енергетичних параметрів семирівневого інвертора джерела напруги в режимі єдиної модулячії та широтно-імпульсної модуляції $з$ різними топологіями.

Ключові слова: автономний інвертор напруги, гармоніки, імітаційна модель, коефіцієнт модуляції, просторово-векторна модулячія, фіксовані діоди, Фур'є-аналіз, широтно-імпульсна модуляџія.

Вступ

Все більше застосування в промисловості знаходять багаторівневі автономні інвертори напруги (БАІН), а саме: у вітровій та сонячній енергетиці, високовольтних підстанціях, у промислових і тягових електроприводах [1]. Порівняно 3 класичними дворівневими інверторами, БАІН мають низку переваг:

- забезпечення більшої вихідної потужності БАІН;

- зменшене значення емісії вищих гармонік у навантаження і мережу живлення;

- зменшення комутаційних втрат у напівпровідникових ключах, що безпосередньо підвищує ККД;

- підвищення синусоїдальності вихідної напруги та струму.

На сьогодні існує кілька топологій багаторівневих $\mathrm{AIH}$, серед яких найбільш поширеними $є$ БАІН 3 фіксованими діодами, БАІН 3 плаваючими конденсаторами, БАІН з каскадним напівмостом [2]. У зв' язку з тим що БАІН з фіксованими діодами знайшли найбільше застосування серед перелічених топологій, то дана стаття присвячена саме цьому типу.

Енергетичні характеристики роботи напівпровідникових перетворювачів, у тому числі й БАІН, багато в чому залежать від застосованого алгоритму керування та типу модуляції, чи то синусоїдальна широтно-імпульсна модуляція (ШІМ), чи одноразова модуляція [3]. При побудові БАІН основними завданнями є: забезпечення максимальної вихідної потужності; мінімізація втрат потужності; забезпечення максимальної синусоїдальності вихідної напруги та струму. У наукових публікаціях [4, 5] наведено системи керування БАІН на основі ШІМ. Такі алгоритми модуляції мають свої переваги та недоліки. До переваг ШІМ слід віднести можливість регулювання амплітуди першої гармоніки вихідного струму, що $\epsilon$ необхідним при скалярному та векторному керуванні. Водночас до недоліків варто віднести високу частоту комутації силових ключів, що призводить до нагрівання напівпровідникових елементів, частин ізоляції перетворювача, збільшення динамічних втрат i, відповідно, до зменшення ККД перетворювача. На сьогоднішній день $є$ й інші гібридні системи ШІМ керування [6], а саме:

- режим рівне-зсунутої ШІМ (англ. Phase Disposition - PD, pис. 1, a);

- режим протидії фаз (англ. Phase Opposition Disposition - POD, pис. 1, б);

- режим альтернативного розташування протифазних сигналів (англ. Alternate Phase Opposition Disposition - APOD, pис. 1, в);

- режим інвертованої синусоїдальної ШІМ (англ. Inverted Sine Carrier PWM - ISCPWM, рис. 1, 2).

(ㄱ В. П. Нерубацький, О. А. Плахтій, Н. П. Карпенко, Д. А. Гордіснко, В. Р. Цибульник, 2019 


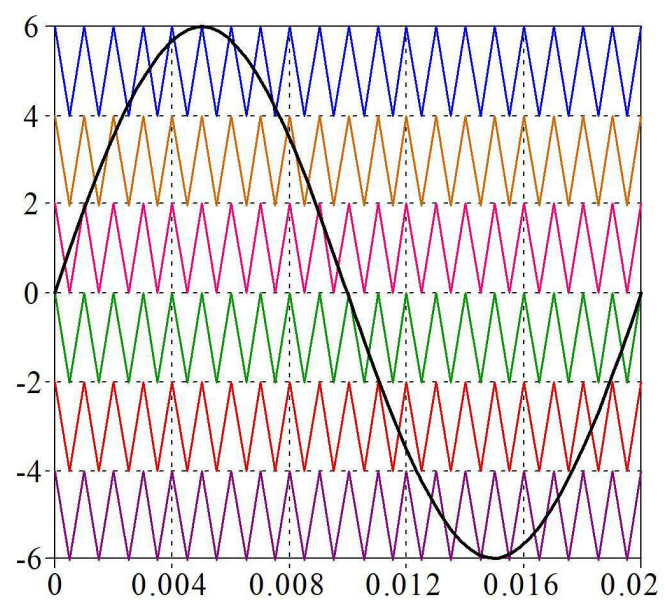

a)

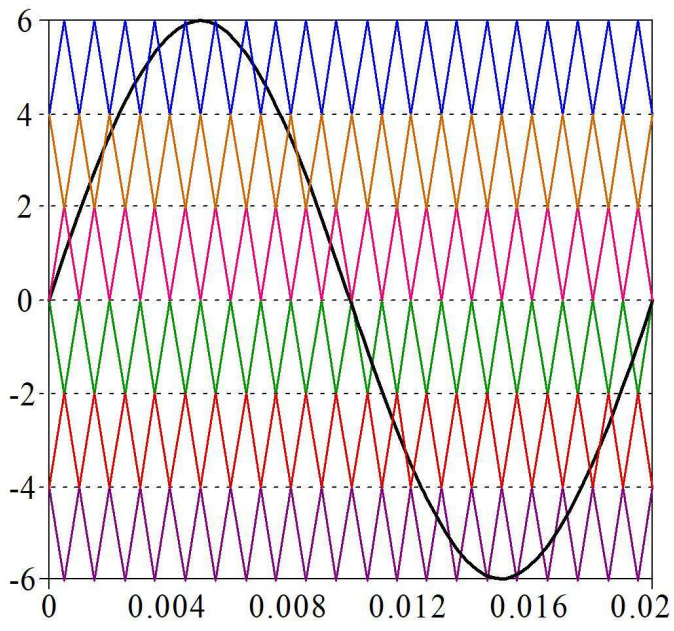

в)

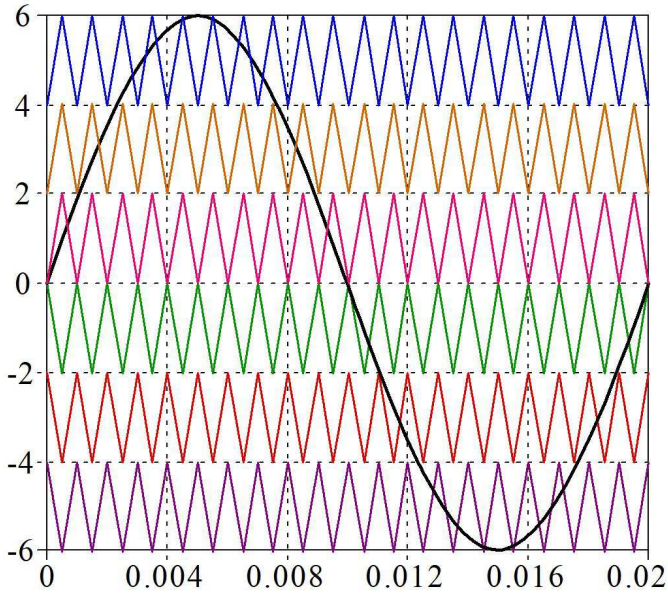

б)

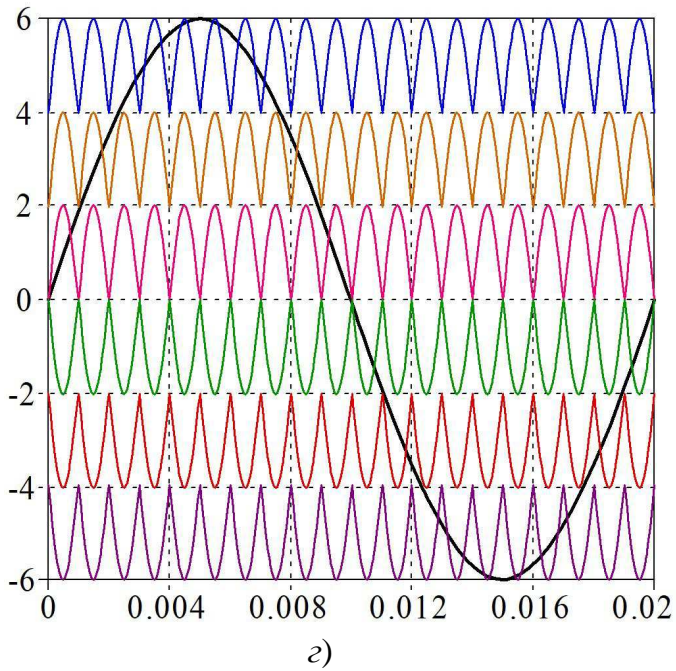

Рис. 1. Режими ШІМ-керування:

$a$ - рівне-зсунута; $\sigma$ - протидії фаз; в - альтернативного розташування протифазних сигналів; г - інвертованої синусоїдальної ШІМ

Перевагою алгоритму просторово-векторної модуляції в БАІН $є$ можливість покращення ряду енергетичних показників [7,8], а саме:

- зниження значення коефіцієнта гармонічних спотворень вихідної напруги, вихідного струму та вхідного струму;

- збільшення вихідної потужності БАІН;

- зниження динамічних втрат у силових напівпровідникових ключах.

\footnotetext{
Мета статті

Дослідження спрямовано на вирішення таких цілей та задач:

- аналіз алгоритму керування ключами семирівневого БАІН, який реалізує режим одноразової модуляції;
}

- визначення енергетичних показників i характеристик електромагнітної сумісності 3 мережею живлення і навантаженням БАІН;

- порівняння отриманих енергетичних характеристик семирівневого БАІН у режимі ШІМ різних типів та у режимі просторово-векторної модуляції.

\section{Виклад основного матеріалу}

Силову схему семирівневого АІН наведено на рис. 2. Перетворювач складається з 6 джерел постійної напруги, 36 силових IGBT-транзисторів і 30 фіксованих діодів. 


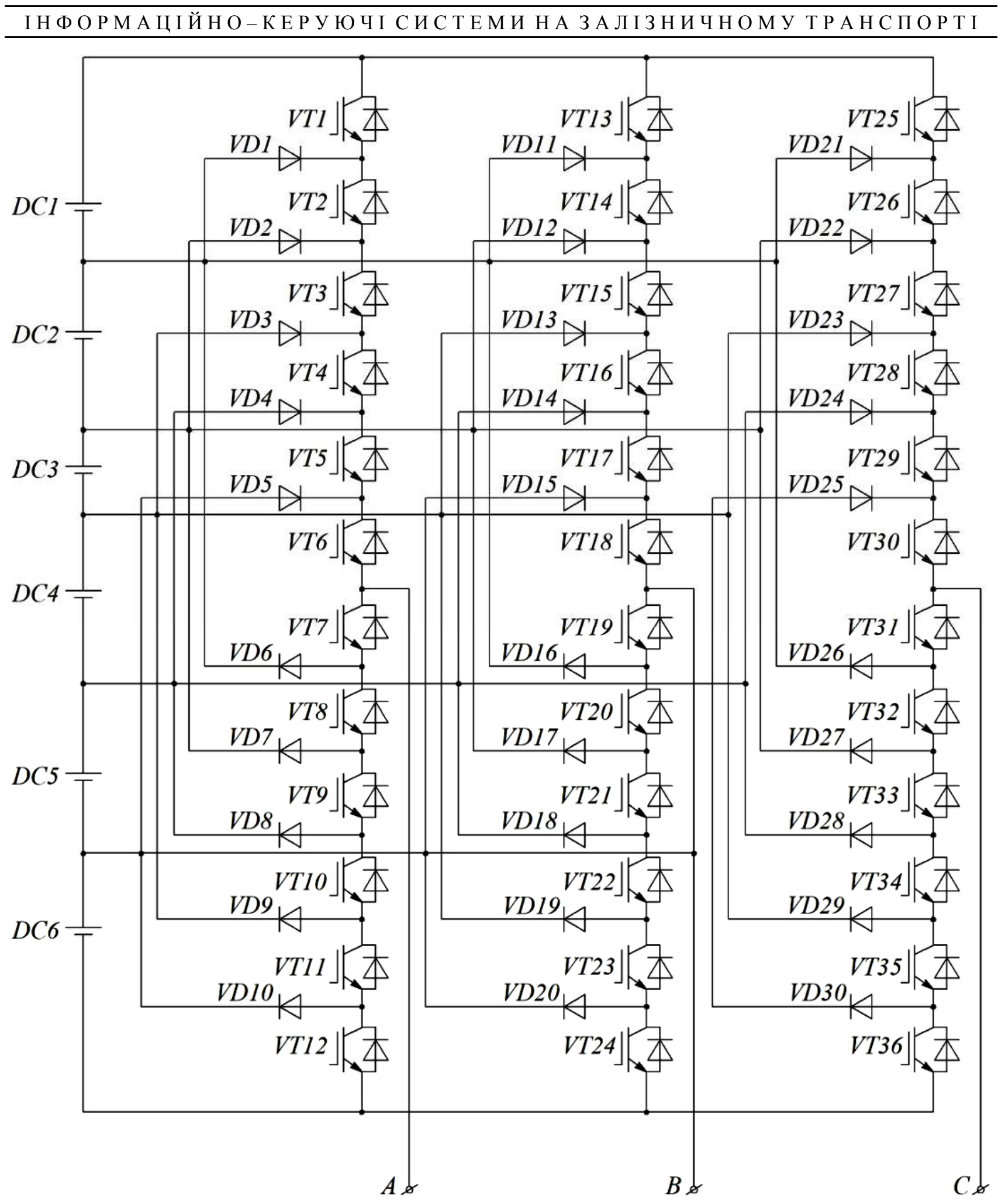

Рис. 2. Силова схема семирівневого АІН

Для реалізації режиму просторово-векторної модуляції ключі семирівневого АІН мають працювати відповідно до алгоритму, де кожен ключ АІН за період вихідної напруги перемикається 3 частотою вихідної напруги $[9,10]$. На рис. 3 наведено комутаційні положення ключів семирівневого АIH з просторововекторною ШІМ. 


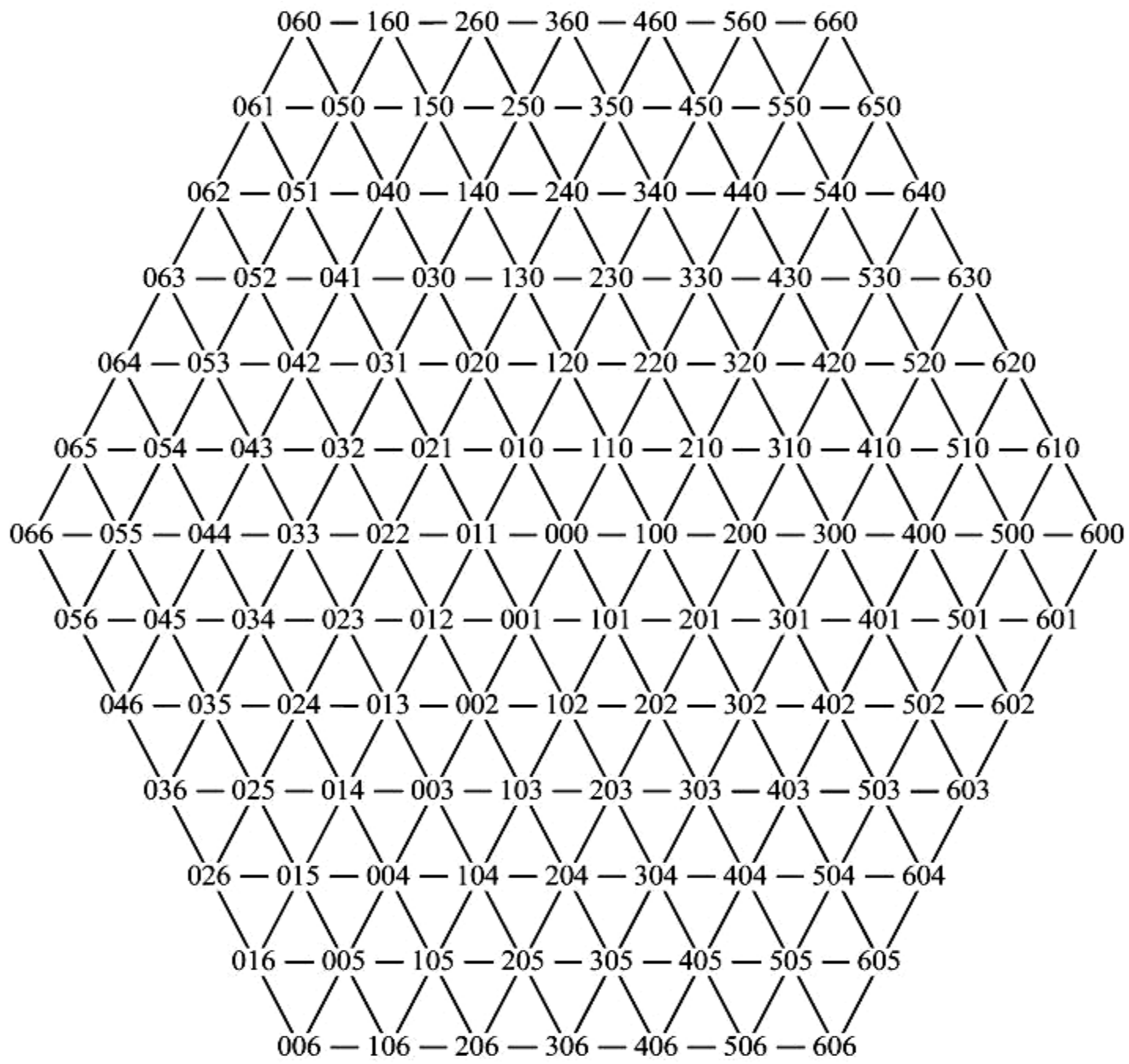

Рис. 3. Комутаційні положення ключів семирівневого АІН

Для дослідження енергетичних характеристик семирівневого АІН у режимі просторово-векторної та режиму ШІМ 3 різними топологіями в програмі Matlab / SymPowerSystems було розроблено універсальну імітаційну модель, що наведено на рис. 4.

Моделювання проводилося 3 такими параметрами:

- напруга живлення в колі постійного струму: 3 кВ;

- активний опір навантаження: 4 Ом;

- індуктивність вихідного дроселя навантаження: $1 \mathrm{м} \Gamma \mathrm{H}$

- частота вихідної напруги: 50 Гц;

- частота опорного сигналу в режимі ШІМ: 1 кГц.

Результати моделювання форми вихідної напруги та вихідного струму фази А семирівневого АIH у режимі просторово-векторної модуляції наведено на рис. 5.

Результати Фур'є-аналізу вихідної напруги та вихідного струму в режимі просторово-векторної модуляції наведено на рис. 6.
Результати моделювання форми вихідної напруги фази А семирівневого АIH у режимі ШIM 3 використанням топологій PD, POD, APOD, ISCPWM 3 частотою 1 кГц наведено на рис. 7.

Фур'є-аналіз вихідної напруги семирівневого АIH у режимі ШІМ з використанням топологій $\mathrm{PD}$, POD, APOD, ISCPWM наведено на рис. 8. 


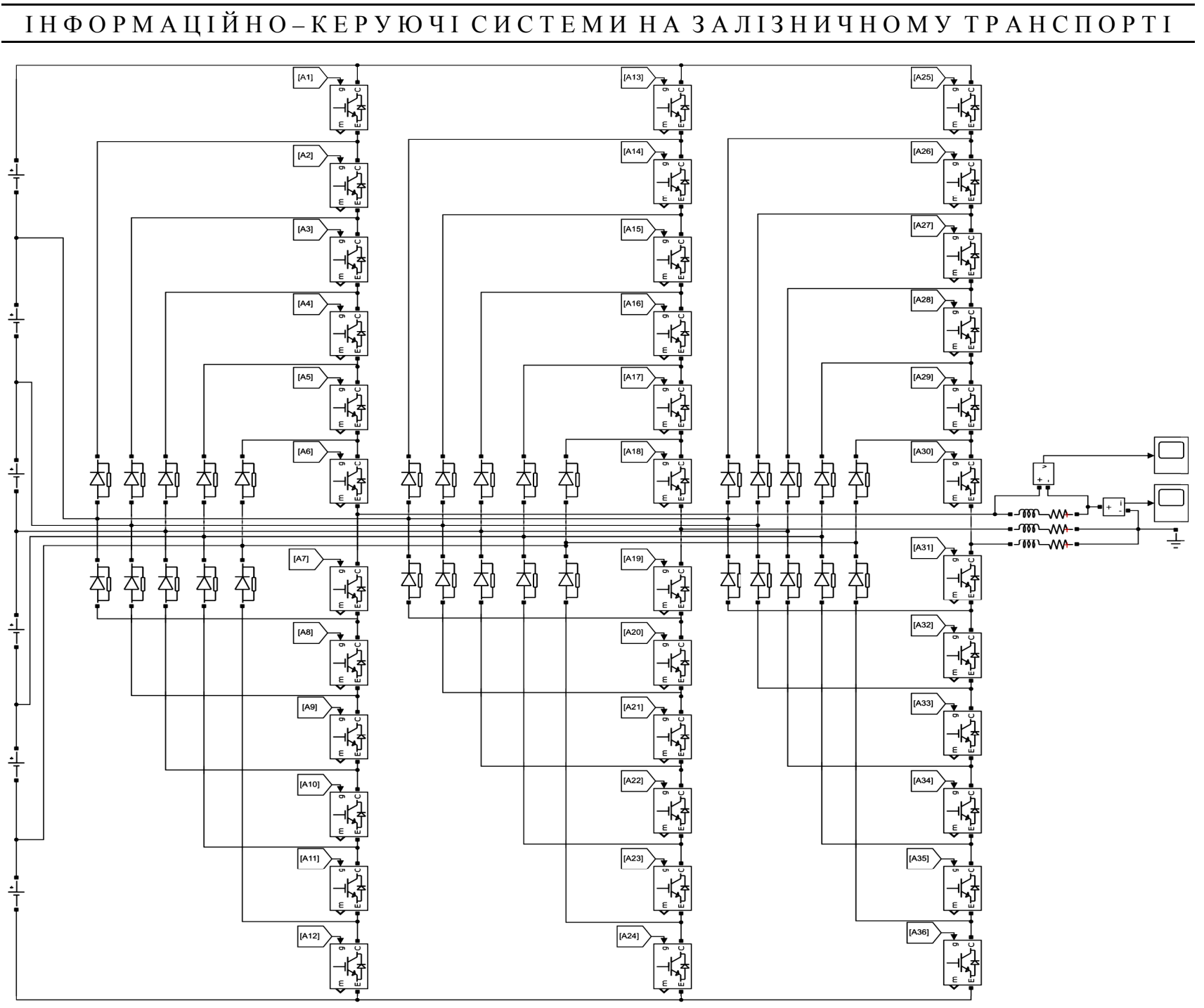

Рис. 4. Імітаційна модель семирівневого АІН з фіксованими діодами

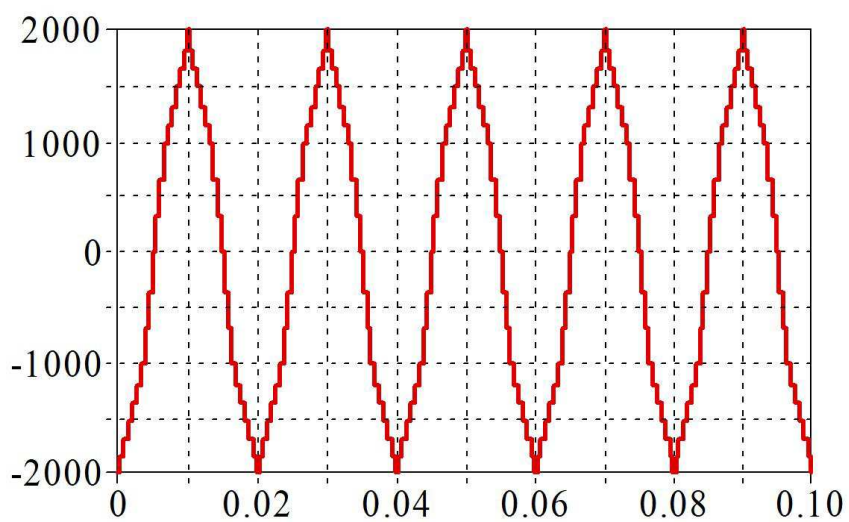

a)

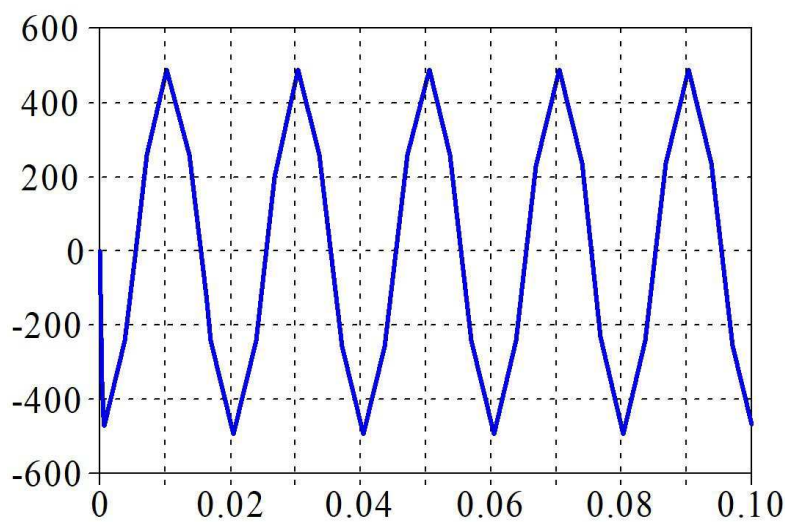

б)

Рис. 5. Результати імітаційного моделювання роботи семирівневого АIH: $a$ - форма вихідної напруги; $\sigma$ - форма вихідного струму 

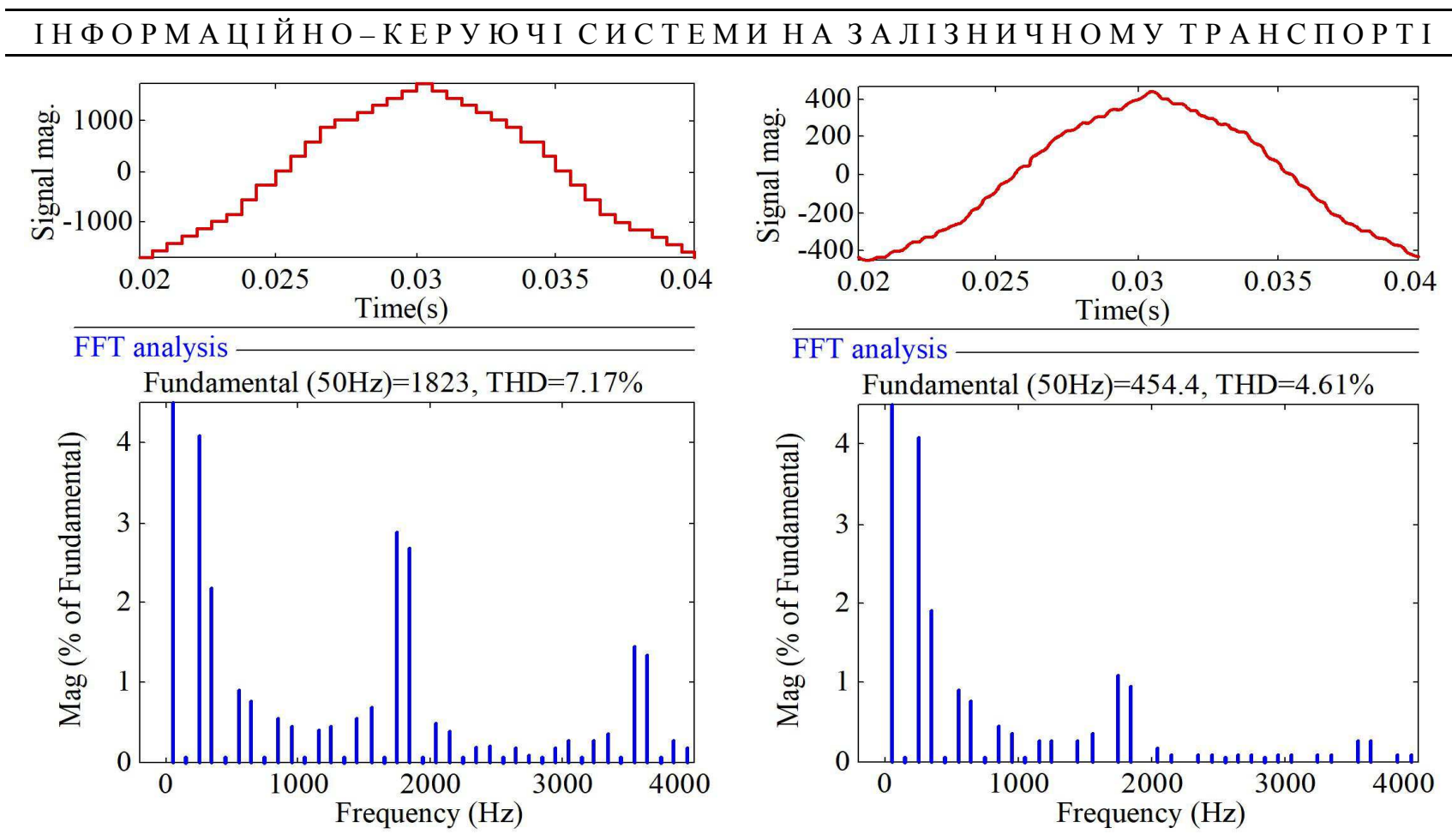

a)

б)

Рис. 6. Результати Фур'є-аналізу режиму просторово-векторної модуляції: $a$ - вихідної напруги; $\sigma$ - вихідного струму

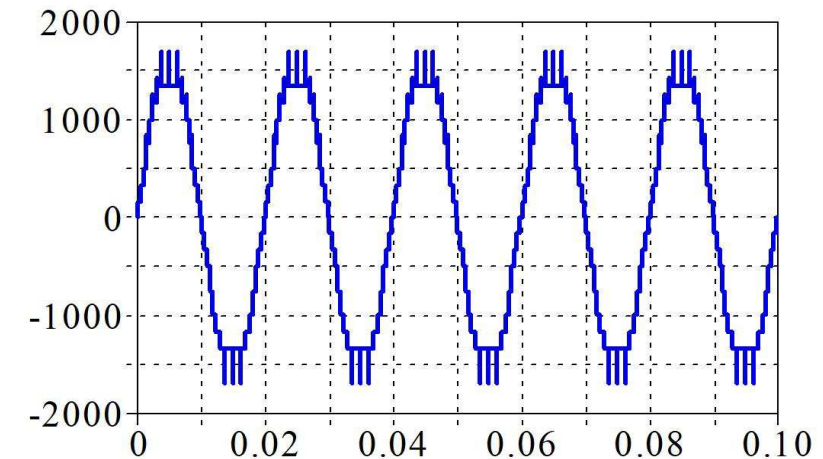

a)

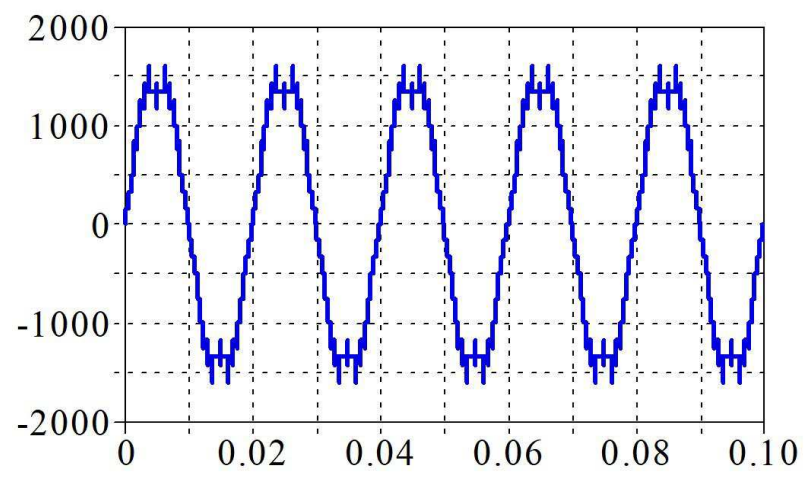

в)

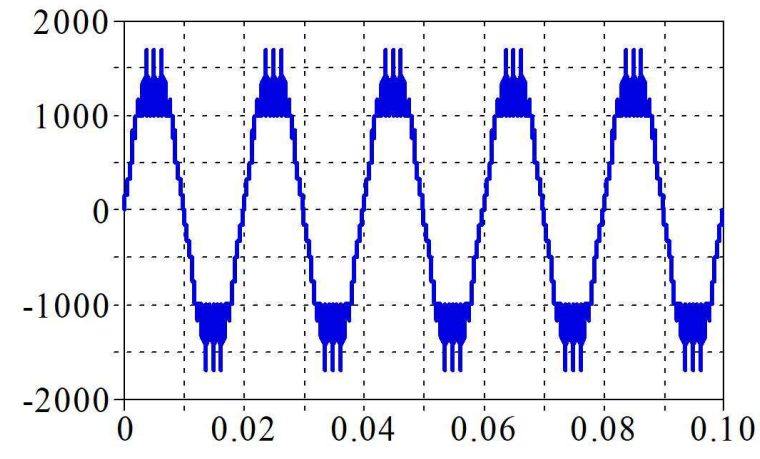

б)



2)

Рис. 7. Результати моделювання форми вихідної напруги фази А: $a$ - PD; $\sigma$ - POD; $в$ - APOD; 2 - ISCPWM 

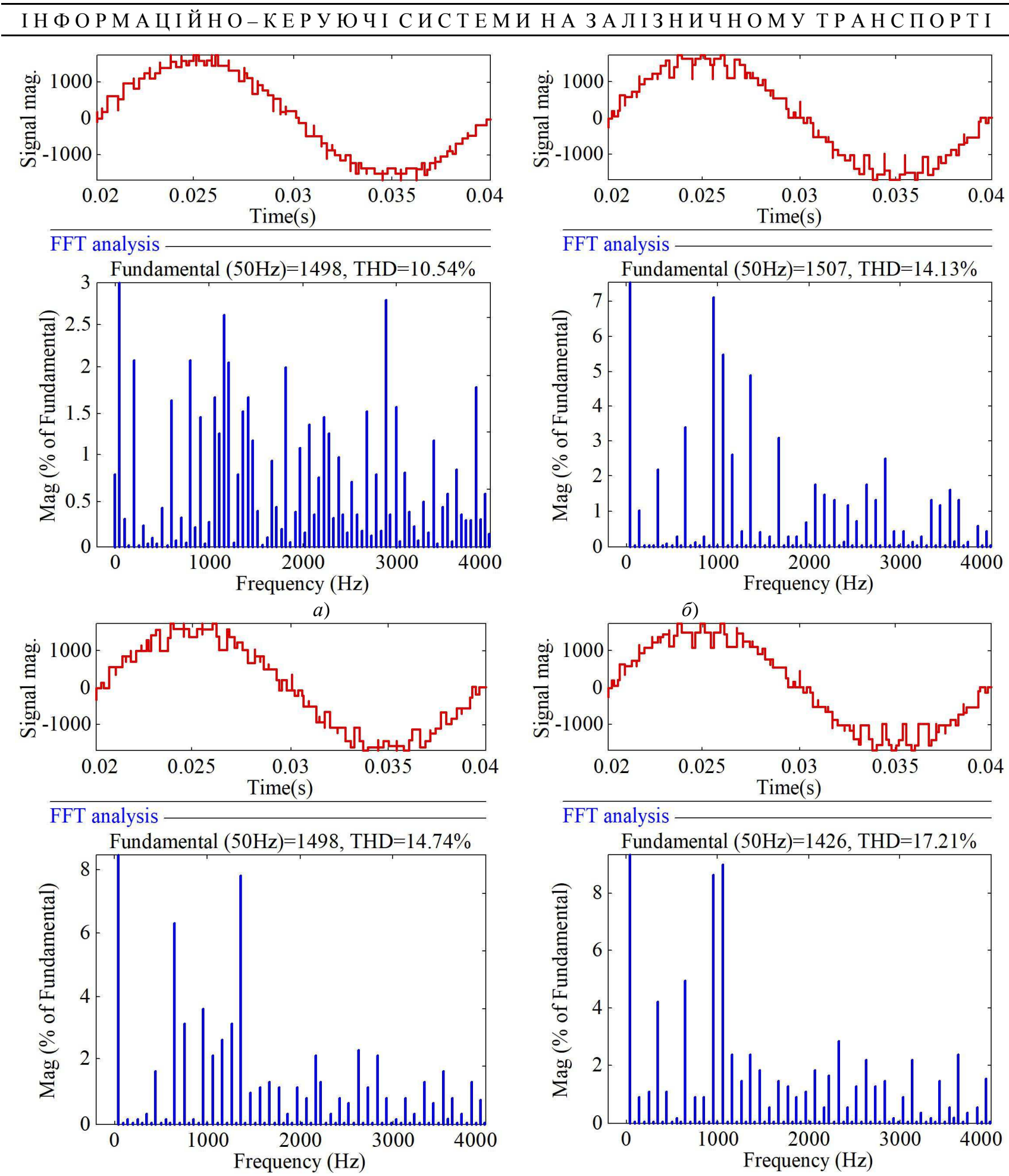

в)



2)

Рис. 8. Фур'є аналіз вихідної напруги з використанням топологій: $a$ - PD; $\sigma$ - POD; $в$ - APOD; 2 - ISCPWM

Іншим перспективним методом підвищення енергетичних показників семирівневого АIH $\epsilon$ застосування покращеного режиму інвертованої синусоїдальної ШІМ $[11,12]$. На рис. 9, $a$ наведено модифіковану рівне-зсунуту ШІМ. Результати моделювання форми вихідної напруги наведено на рис. 9,6 .

Фур'є-аналіз вихідної напруги в режимі покращеної ШІМ наведено на рис. 10. 


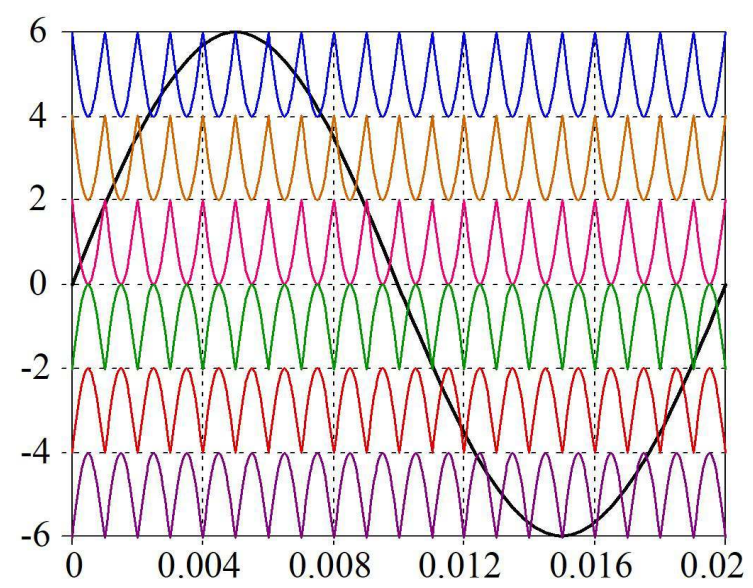

a)

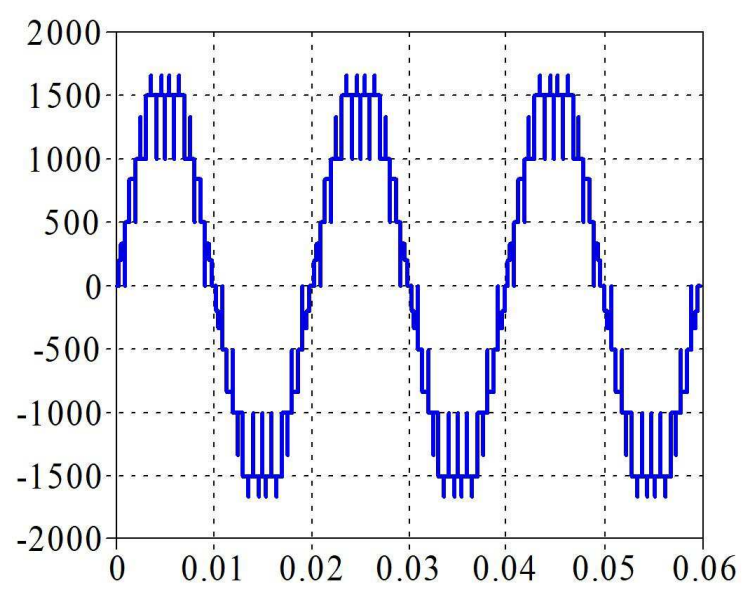

б)

Рис. 9. Режим модифікованої ШІМ ( $а$ ) та форма її вихідної напруги (б)
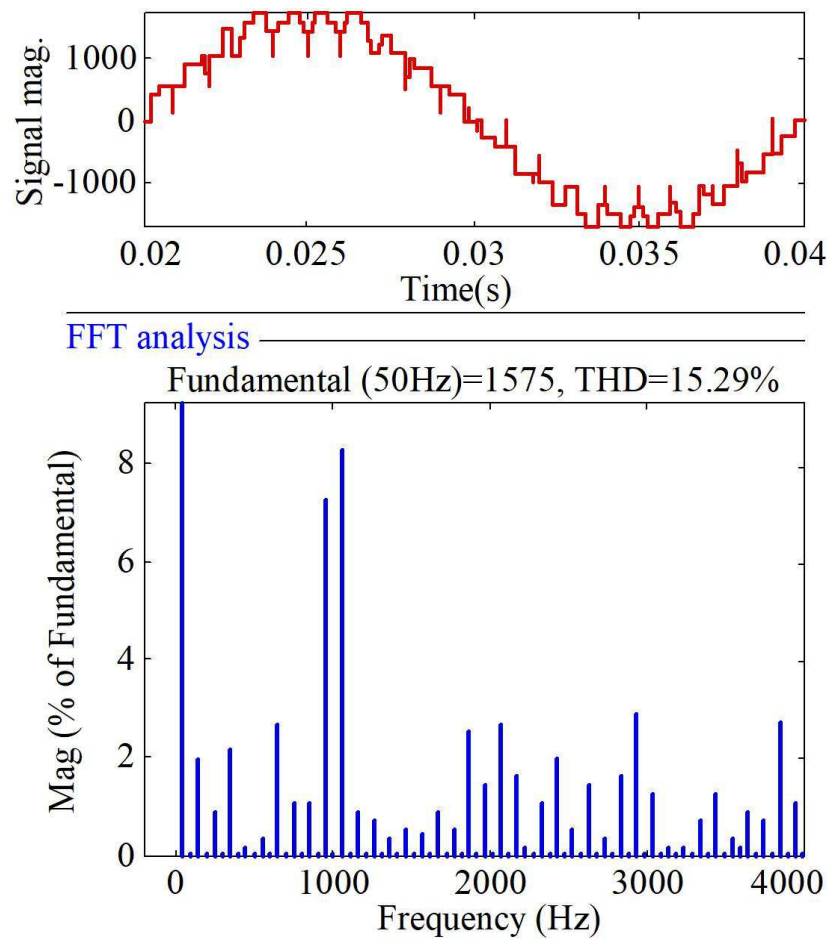

Рис. 10. Фур'є-аналіз вихідної напруги в режимі покращеної ШІМ

Визначення втрат потужності в IGBT-транзисторах може бути виконано шляхом розрахунку статичних $P_{D C}$ та динамічних $P_{S W}$ втрат в IGBT-транзисторах і паралельних діодах [13, 14]:

$P=P_{D C}+P_{S W}$,

де $P_{D C}-$ статичні втрати в IGBT-транзисторах; $P_{S W}-$ динамічні втрати в IGBT-транзисторах.
Процес комутації струму та напруги в IGBT-ключі й графічний розподіл статичних $\mathrm{i}$ динамічних втрат наведено на рис. 11.

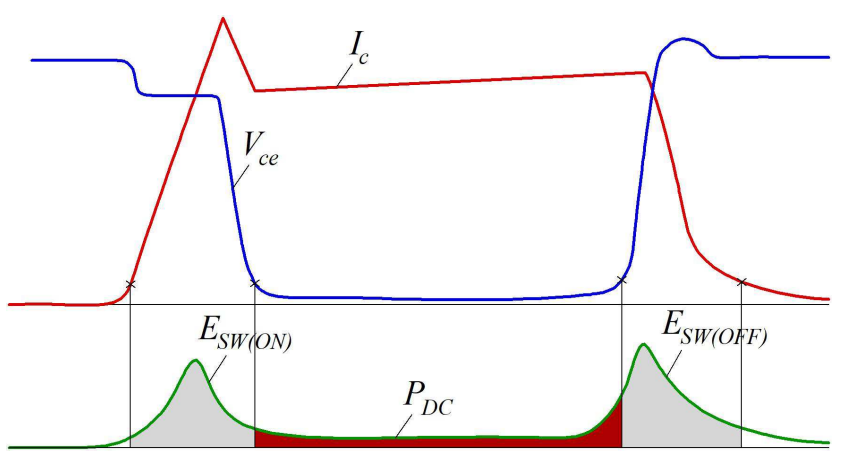

Рис. 11. Процес комутації струму та напруги в IGBT-ключі

Статичні втрати в IGBT-транзисторах $P_{D C}$ визначаються відповідно до виразу:

$P_{D C}=\frac{1}{2 \pi} \cdot \int_{0}^{\pi}\left(I_{c} \cdot V_{c e}\left(I_{c}\right) \cdot D_{o n}\right) d t$,

де $I_{c}$ - струм колектора; $V_{c e}\left(I_{c}\right)$ - напруга між колектором i емітером, що залежить від величини струму колектора (залежність $V_{c e}\left(I_{c}\right)$ подано в документації на транзистор); $D_{o n}-$ коефіцієнт заповнення ШІМ.

Динамічні втрати в IGBT-транзисторах $P_{S W}$ визначаються відповідно до виразу:

$P_{S W}=\frac{1}{2 \pi} \int_{0}^{\pi}\left(E_{\text {ON }}\left(I_{c}\right)+E_{\text {OFF }}\left(I_{c}\right) \cdot f\right) d t$, 
де $f$ - частота ШІМ; $E_{O N}\left(I_{c}\right)$ - енергія, що розсіюється в транзисторі при вмиканні, яка залежить від величини струму колектора; $E_{O F F}\left(I_{c}\right)$ - енергія, що розсіюється в транзисторі при вимиканні, яка залежить від величини струму колектора.

Для знаходження сумарних втрат $P_{\text {loss }}$ в автономному інверторі напруги необхідно просумувати втрати потужності в одному плечі та помножити на 6:

$P_{\text {loss }}=\left(P_{1}+P_{2}+P_{3}+P_{4}+P_{5}+P_{6}\right) \cdot 6$,

де $P_{1 \div 6}-$ втрати потужності в IGBT-транзисторах одного плеча.

Оцінка ККД АІН визначається за виразом:
$\eta=\frac{\left(P_{i n}-P_{\text {loss }}\right)}{P_{\text {in }}} \cdot 100$,

де $P_{\text {in }}-$ вхідна потужність АІН.

У табл. 1 наведено результати моделювання семирівневого АIH в режимі просторово-векторної модуляції та в режимах ШІМ з використанням різних топологій. Застосування семирівневої топології активного випрямляча дозволяє застосовувати ключі меншого класу для реалізації тієї самої напруги в колі постійного струму. При цьому характерною особливістю ключів меншого класу $є$ менше падіння між колектором та емітером, а також менша енергія перемикання.

Результати моделювання семирівневого АIH

Таблиця 1

\begin{tabular}{|c|c|c|c|c|c|c|}
\hline \multirow[b]{2}{*}{ Показники } & \multirow{2}{*}{$\begin{array}{l}\text { Просторово- } \\
\text { векторна } \\
\text { модуляція } \\
\end{array}$} & \multicolumn{5}{|c|}{ Широтно-імпульсна модуляція } \\
\hline & & PD & POD & APOD & ISCPWM & $\begin{array}{c}\text { Покращена } \\
\text { ISCPWM }\end{array}$ \\
\hline $\begin{array}{l}\text { Частота опорного сигналу, } \\
\text { Гц }\end{array}$ & 50 & 1000 & 1000 & 1000 & 1000 & 1000 \\
\hline $\begin{array}{l}\text { Амплітуда першої } \\
\text { гармоніки вихідної } \\
\text { напруги, В }\end{array}$ & 1823 & 1498 & 1507 & 1498 & 1426 & 1575 \\
\hline $\begin{array}{l}\text { Амплітуда першої } \\
\text { гармоніки вихідного } \\
\text { струму, А }\end{array}$ & 899,2 & 454 & 373,3 & 373,3 & 355,3 & 392,6 \\
\hline $\begin{array}{l}\text { Коефіцієнт гармонічних } \\
\text { спотворень вихідної } \\
\text { напруги, \% }\end{array}$ & 7,17 & 10,5 & 14,13 & 14,74 & 17,21 & 15,29 \\
\hline $\begin{array}{l}\text { Коефіцієнт гармонічних } \\
\text { спотворень вихідного } \\
\text { струму, \% }\end{array}$ & 3,71 & 4,61 & 4,03 & 6,97 & 8,9 & 7,17 \\
\hline $\begin{array}{l}\text { Статичні втрати в IGBT- } \\
\text { ключі, Вт }\end{array}$ & 5770,8 & 4163,7 & 4154 & 4136,1 & 3795 & 4532,8 \\
\hline $\begin{array}{l}\text { Динамічні втрати в IGBT- } \\
\text { ключі, Вт }\end{array}$ & 15,8 & 75,3 & 54,1 & 67,7 & 54 & 78,2 \\
\hline Сумарні втрати в АІН, Вт & 5786,6 & 4239 & 4208,1 & 4203,8 & 3849 & 4611 \\
\hline ККД, \% & 99,54 & 99,5 & 99,51 & 99,51 & 99,49 & 99,5 \\
\hline
\end{tabular}

Висновки i рекомендації щодо подальшого використання

У статті проведено порівняльний аналіз роботи семирівневого інвертора напруги 3 різними типами ШІМ-модуляції. Для аналізу ефективності розглянутих алгоритмів у програмі Matlab було розроблено імітаційну модель семирівневого інвертора джерела напруги з фіксованими діодами. Встановлено значення вихідної потужності, загальні коефіцієнти гармонічних спотворень вихідної напруги та вихідного струму, а також значення втрат потужності в силових перемикачах.

Встановлено, що коефіцієнт гармонічних спотворень вихідного струму у режимі просторововекторної модуляції складає $3,71 \%$ і має кращий показник порівняно 3 іншими режимами ШІМ. Водночас менші втрати потужності в АIH має режим інвертованої синусоїдальної ШІМ, що складає 3849 Вт. Як наслідок, зі збільшенням числа рівнів АІН будуть зменшуватися втрати в IGBT-транзисторах. 


\section{Список використаних джерел}

1. Ghorbani M., Mokhtari H. Impact of harmonics on power quality and losses in power distribution systems. International Journal of Electrical and Computer Engineering (IJECE). 2015. Vol. 5, No. 1. P. 166-174.

2. Saygin A., Kerem A. Fuzzy logic control loaded asynchronoys motor using a 6-switched 3-level inverter. 18th International Conference on Computational Problems of Electrical Engineering (CPEE). 2017. P. 117-125.

3. Riba J. Analysis of formulas to calculate the AC resistance of different conductors configurations. Electric Power Systems Research. 2015. Vol. 127. P. 93-100.

4. Colak K., Asa E., Czarkowski D. A novel phase control of single switch active rectifier for inductive power transfer applications. 2016 IEEE Applied Power Electronics Conference and Exposition (APEC). 2016. P. 1767-1772.

5. Guo B., Wang F., Aeloiza E. Modulation scheme for delta-type current source rectifier to reduce input current distortion. 2014 IEEE Energy Conversion Congress and Exposition (ECCE). 2014. P. 40954101.

6. Lee J.-S., Lee K.-B. Carrier-based discontinuous PWM method for Vienna rectifiers. IEEE Transactions on Power Electronics. 2015. Vol. 30, No. 6. P. 2896-2900.

7. Plakhtii O., Nerubatskyi V. Analyses of energy efficiency of interleaving in active voltage-source rectifier. 2018 IEEE 3rd International Conference on Intelligent Energy and Power Systems (IEPS). 2018. P. 253-258.

DOI: https://doi.org/10.1109/IEPS.2018.8559514.

8. Singh D., Bansal P. Power effective asymmetric topology for 7-level multilevel inverter with different PWM techniques. International Journal of Science, Engineering and Technology Research (IJSETR). 2018. Vol. 7, Issue 6. P. 413-417.

9. Plakhtii O., Nerubatskyi V., Ryshchenko I., Zinchenko O., Tykhonravov S., Hordiienko D. Determining additional power losses in the electricity supply systems due to current's higher harmonics. Eastern-European Journal of Enterprise Technologies. 2019. Vol. 1, No. 8 (97). P. 6-13. DOI: https://doi.org/10.15587/17294061.2019.155672.

10. Плахтій О. А., Нерубацький В. П., Сушко Д. Л., Кавун В. С. Зниження динамічних втрат в активному однофазному чотириквадрантному перетворювачі 3 покращеним алгоритмом гістерезисної модуляції. Праці Інституту електродинаміки Національної академії наук України. 2018. Вип. 51. С. 88-94. DOI: https://doi.org/10.15407/publishing2018.51.088.
11. Нерубацький В. П., Плахтій О. А., К Кавун В. С., Машура А. В., Гордієнко Д. А., Цибульник В. Р. Аналіз показників енергоефективності автономних інверторів напруги з різними типами модуляції. Збірник наукових праць Українського державного університету залізничного транспорту. 2018. Вип. 180. С. 106-120.

12. Pillay T., Saha A. Analysis and simulation of flying capacitor multilevel inverter using PDPWM strategy. International Conference on Innovative Mechanisms for Industry Applications (ICIMIA). 2017. P. 10611070.

13. Zhao, G. I., Wang, L., Li, Q., Chen, G. Analyze and compare the efficiency of two-level and three-level inverter in SVPWM. 9th IEEE Conference on Industrial Electronics and Applications. 2014. P. 1954-1958.

DOI: https://doi.org/10.1109/iciea.2014.6931488.

14. Wintrich, A., Ulrich, N., Kolpakov, A. I., Mysak, T. V., Polishchuk, S. I. Analysis of Dynamic Loss of Powerful IGBTs. Bulletin of the National Technical University «Kharkiv Polytechnic Institute». 2017. No. 27. P. 191-196.

В. П. Нерубацкий, А. А. Плахтий, Н. П. Карпенко, Д. А. Гордиенко, В. Р. Цыбульник. Анализ энергетических процессов В семиуровневом автономном инверторе напряжения при различных алгоритмах модуляции.

Аннотация. В статье исследованы реализованные параметры качества выходного напряжения и выходного тока в семиуровневом автономном инверторе напряжения с фиксированными диодами при реализации различных алгоритмов модуляции. Рассмотрены методы реализации широтно-импульсной модуляции. В среде Matlab / Simulink / SymPowerSystems разработана модель семиуровневого автономного инвертора напряжения с рассмотренными системами управления. Получены результаты имитационного моделирования в виде энергетических показателей. Установлено значение выходной мощности, общие коэффициенты гармонических искажений выходного напряжения и выходного тока, а также значение потерь мощности в силовых переключателях. Приведена сравнительная таблица энергетических параметров семиуровневого инвертора источника напряжения в режиме единой модуляции и широтно-импульсной модуляции с разными топологиями.

Ключевые слова: автономный инвертор напряжения, гармоники, имитационная модель, коэффициент модуляции, пространственно-векторная модуляция, фиксированные диоды, Фурье-анализ, широтноимпульсная модуляция. 
V. P. Nerubatskyi, O. A. Plakhtii, N. P. Karpenko, D. A. Hordiienko, V. R. Tsybulnyk. Analysis of energy processes in a seven-level autonomous voltage inverter at various modulation algorithms.

Abstract. The most commonly used in autonomous voltage inverter (AVI) is pulse-width modulation (PWM) and single modulation. The advantage of PWM prior to single modulation is the ability to control the amplitude of the first harmonic of the output voltage and, accordingly, the current required both for scalar and vector control of an asynchronous electric drive.

Multilevel autonomous voltage inverters (MAVI) are finding increasing application in industry, namely: in wind and solar power engineering, high-voltage substations, in industrial and traction electric drives. In comparison with the classical two-level inverters, MAVI have several advantages: providing greater output power MAVI, the reduced value of the emission of higher harmonics in the load and the supply network, reduction of switching losses in semiconductor switches, which directly increases the efficiency, increased sinusoidal output voltage and current.

Currently, there are several topologies of multilevel AVI, among which the most common are MAVI with fixing diodes, MAVI with convertible capacitors, MAVI with cascade half-bridge. Due to the fact that the MAVI with fixing diodes found the greatest use among the listed topologies, this article is dedicated to this type.

The article examines the realizable quality parameters of the output voltage and output current in a seven-level AVI with fixing diodes during the implementation of various modulation algorithms. Methods for the implementation of PWM are considered. In Matlab / Simulink / SymPowerSystems, a seven-level AVI model has been developed with considered control systems. The results of simulation in the form of energy indicators, namely the harmonic distortion of the output current and voltage, are obtained.

Results of studies of a multi-bridge active voltagesource rectifier in the interleaving mode are presented. Based on the energy balance equation were obtained relation that determine the adjusting characteristic of the output voltage in the rectification and recovery modes. Were developed Matlab models of active multi-bridge rectifiers with different number of parallel bridges and different PWM frequencies. It is established that interleaving in the active rectifier allows to significantly reduce the switching frequency of the input current. At the same time, it's significantly reduces power losses in power switches and increases the efficiency of the active rectifier. Interleaving provides compensation of the higher harmonics of the input current. It is established that the coefficient of harmonic distortions of the output current in the mode of spatial - vector modulation is $3,71 \%$, and has a better index, in comparison with other modes of PWM. At the same time, lower power losses in AVI have a mode of inverted sinusoidal PWM and is $3849 \mathrm{~W}$. As a result, with an increase in the number of AVI level, IGBTtransistors will also decrease losses.

Key words: autonomous voltage inverter, harmonics, simulation model, modulation coefficient, spatial-vector modulation, fixed diodes, Fourier analysis, pulse-width modulation.

Надійшла 01.07.2019

Нерубацький Володимир Павлович, к.т.н., доцент кафедри електроенергетики, електротехніки та електромеханіки. Украӥнський державний університет залізничного mpaнсnорту. E-mail: NVP9@i.ua. ORCID: https://orcid.org/0000-0002-4309-601X

Плахтій Олександр Андрійович, к.т.н., доцент кафедри електроенергетики, електротехніки та електромеханіки. Український державний університет залізничного mpaнсnорту. E-mail: a.plakhtiy1989@gmail.com. ORCID: https://orcid.org/0000-0002-1535-8991

Карпенко Надія Петрівна, к.т.н., доиент кафедри електроенергетики, електротехніки та електромеханіки. Украйнський державний університет залізничного mpaнсnорту. E-mail: kanape1909@gmail.com ORCID: https://orcid.org/0000-0002-9252-9934

Гордієнко Денис Анатолійович, аспірант, Украӥнський державний університет залізничного транспорту. E-mail: D.Hordiienko@i.ua._ORCID: https://orcid.org/0000-0002-03475656

Цибульник Владислав Романович, магістрант кафедри електроенергетики, електротехніки та електромеханіки. Украӥнський державний університет залізничного транспорту. E-mail: vladtsybulnyk@gmail.com. ORCID: https://orcid.org/0000-0002-9895-6662

Nerubatskyi Volodymyr Pavlovych, PhD, associate professor, department of electric power engineering, electrical engineering and electromechanics, Ukrainian State University of Railway Transport. E-mail: NVP9@i.ua.ORCID: https://orcid.org/00000002-4309-601X

Plakhtii Olexandr Andrievych, PhD, associate professor, department of electric power engineering, electrical engineering and electromechanics, Ukrainian State University of Railway Transport. E-mail: a.plakhtiv1989@gmail.com. ORCID: https://orcid.org/0000-0002-1535-8991

Karpenko Nadiya Petrivna, PhD, associate professor, department of electric power engineering, electrical engineering and electromechanics, Ukrainian State University of Railway Transport. E-mail: kanape1909@gmail.com. ORCID: https://orcid.org/0000-0002-9252-9934

Hordiienko Denys Anatolievych, postgraduate, department of electric power engineering, electrical engineering and electromechanic Ukrainian State University of Railway Transport. E-mail: $\quad$ D.Hordiienko@i.ua ORCID: https://orcid.org/0000-0002-0347-5656 E-mail:D.Hordiienko@i.ua._ORCID: https://orcid.org/00000002-0347-5656

Tsybulnyk Vladyslav Romanovych, master's degree, department of electric power engineering, electrical engineering and electromechanics, Ukrainian State University of Railway Transport. E-mail: vladtsybulnyk@gmail.com. ORCID: https://orcid.org/0000-0002-9895-6662 